\title{
Genetic influences on creativity: an exploration of convergent and divergent thinking
}

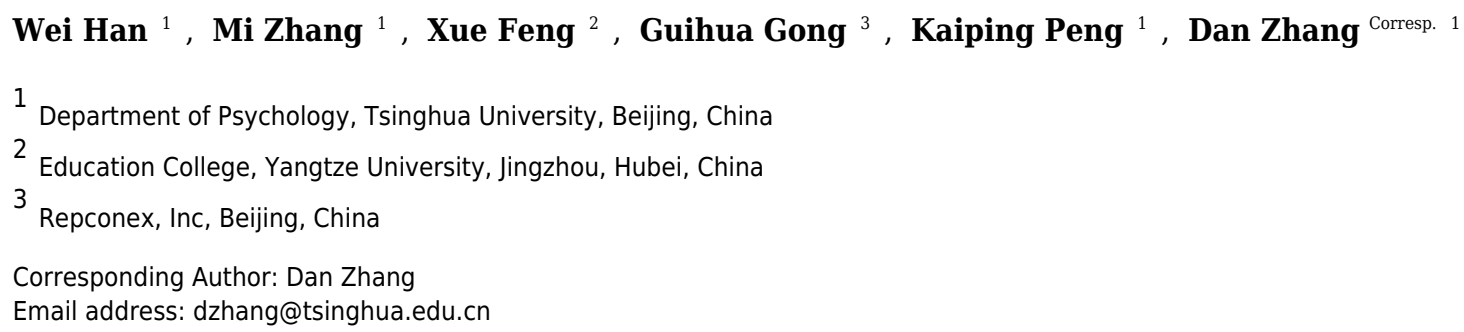

Previous studies on the genetic basis of creativity have mainly focused on the biological mechanisms of divergent thinking, possibly limiting the exploration of possible candidate genes. Taking a cognition-based perspective, the present study investigated the genetic basis for both the divergent and the convergent thinking components of creativity. 321 Chinese university students were recruited to complete the Guildford Unusual Using Test (UUT) for divergent thinking capability and the Remote Associates Test (RAT) for convergent thinking capability. The polymorphism of rs2576037 in KATNAL2 was related to the fluency and originality component scores of UUT, and the polymorphism of rs5993883 in COMT, rs362584 in SNAP25 was related to the RAT performance. These effects remained significant after considering the influence of age, gender and intelligence. Our results provide new evidence for the genetic basis of creativity and reveal the important role of gene polymorphisms in divergent and convergent thinking. 


\section{Genetic Influences on Creativity: An Exploration of}

\section{Convergent and Divergent Thinking}

3 Wei Han ${ }^{\mathrm{a}, 1}$, Mi Zhang ${ }^{\mathrm{a}, 1}$, Xue Feng ${ }^{\mathrm{b}}$, Guihua Gong ${ }^{\mathrm{c}}$, Kaiping Peng a, Dan Zhang a,*

5 a Department of Psychology, Tsinghua University, Beijing 100084, P.R. China

6 b Education College, Yangtze University, Jingzhou 434023, P.R. China

$7 \quad$ c Repconex Bio-Tech Co., Ltd., Beijing 100085, P.R. China

8

91 Authors equally contributed to this paper

11 Corresponding Author:

12 Dan Zhang, Ph.D. ${ }^{a}$

13 Department of Psychology, School of Social Sciences, Tsinghua University

14 Beijing 100084, China

15 Tel.: 86-10-62773687

16 E-mail: dzhang (at) tsinghua.edu.cn 


\section{Abstract}

19 Previous studies on the genetic basis of creativity have mainly focused on the biological

20 mechanisms of divergent thinking, possibly limiting the exploration of possible candidate genes.

21 Taking a cognition-based perspective, the present study investigated the genetic basis for both

22 the divergent and the convergent thinking components of creativity. 321 Chinese university

23 students were recruited to complete the Guildford Unusual Using Test (UUT) for divergent

24 thinking capability and the Remote Associates Test (RAT) for convergent thinking capability.

25 The polymorphism of rs2576037 in KATNAL2 was related to the fluency and originality

26 component scores of UUT, and the polymorphism of rs5993883 in COMT, rs362584 in SNAP25

27 was related to the RAT performance. These effects remained significant after considering the

28 influence of age, gender and intelligence. Our results provide new evidence for the genetic basis

29 of creativity and reveal the important role of gene polymorphisms in divergent and convergent

30 thinking. 


\section{Introduction}

34 Creativity, the ability to develop new and useful ideas, is the key driving force behind

35 scientific, technological and cultural innovation (Sternberg \& Lubart, 1999; Diedrich et al.,

36 2015). Given the widely acknowledged importance of creativity, studying its psychological basis

37 has attracted much attention in past decades. With recent advances in molecular genetics,

exploring the genetic basis of creativity has attracted increasing interest in the field of

psychology as well. Finding creativity characteristic genes would help explain the individual differences in creative behaviors, providing a deeper understanding of the biological and the psychological basis of creativity.

The majority of genetic exploration on creativity has taken a biological perspective, with a special focus on the dopamine (DA) system (Reuter et al., 2006; Runco et al., 2011; Mayseless et al., 2013; Zhang, Zhang \& Zhang, 2014a). Within the dopamine (DA) system, the dopamine D2 receptor gene (DRD2) and the catechol-O-methyltransferase gene (COMT) are of most interest. Several single nucleotide polymorphisms (SNPs) in DRD2 have been found to be related to divergent thinking capability measured either by behavioral tests or by self-report (Reuter et al., 2006; Zhang, Zhang \& Zhang, 2014a; Takeuchi et al., 2015; Yu, Zhang \& Zhang, 2017). Among them, the effect of rs1800497 was first reported in the Caucasian population (Reuter et al., 2006), with two follow-up reports in Han Chinese population as well (Yu et al., 2017; Zhang et al.,

51 2014a; but see Takeuchi et al., 2015 in which a null result was reported with the Japanese

52 population). Likewise, the polymorphism of rs4648319 was found related to fluency and 
53 flexibility components of the Runco Ideational Behavior Scale (RIBS) (Yu, Zhang \& Zhang,

54 2017), as well as verbal fluency measured by selected divergent tasks of the Runco Creativity

55 Assessment Battery (rCAB) (Zhang, Zhang \& Zhang, 2014a). Findings on COMT gene were

56 more controversial. While several SNPs in COMT (rs174697, rs737865, rs5993883, rs4680)

57 were associated with performances in divergent thinking tasks of rCAB (Zhang, Zhang \& Zhang,

58 2014b), other studies failed to find any main effect on either divergent thinking performance in

59 the Abbreviated Torrance Test for Adults (ATTA) or real-life creative achievement measured by

60 the Creative Achievement Questionnaire (CAQ) (Zabelina et al., 2016). Also, individuals

61 carrying the DRD4-7R allele were found to score significantly lower on divergent thinking tasks

62 compared to non-carriers (Mayseless et al., 2013). Researchers have also reported creativity

63 characteristic genes other than the DA system. Several SNPs on 5-HT-related tryptophan

64 hydroxylase (TPH) gene have been found to be associated with the performances in divergent

65 thinking tasks as well (Reuter et al., 2006; Zhang \& Zhang, 2017). One SNP in the oxytocin

66 receptor gene (OXTR), rs 1042778, predicted participants' fluency, flexibility, and originality of

67 divergent creative ideation measured by the Alternative Using Task (De Dreu et al., 2014).

68 Notably, the above-mentioned genetic studies have primarily employed divergent thinking

69 task performances as the behavioral indicator for creativity. While divergent thinking capability

70 is probably the most well studied component of creativity, convergent thinking has received

71 increasing attention in recent years (Brophy, 2001; Lee \& Therriault, 2013). Divergent and

72 convergent thinking processes are believed to provide complementary roles for constituting 
73 creative behaviors (Guilford, 1967): Whereas divergent thinking refers to the generation of

74 multiple ideas or solutions for a single problem, convergent thinking is associated with finding a

75 single solution to a problem in an analytical and deductive way. The major distinction is that the

76 former starts from a single point and generates multiple ideas, whereas the latter starts from

77 multiple points and seeks for a single solution (Brophy, 2001). Accordingly, distinct tasks have

78 been designed to measure these two processes. Divergent thinking tests, such as Guildford

79 Unusual Using Test (UUT) (Guilford, 1967), require participants to generate a broad range of

80 ideas to a given stimuli. Remote Associates Test (RAT), on the other hand, has a structure

81 dictated by the definition of convergent thinking, which involves finding a criteria-meeting

82 mediating link to combine stimulus from mutually remote associative clusters (Mednick, 1962).

83 To the best of our knowledge, there are only two recent genetic studies on insight problem

84 solving that are related to convergent thinking. In both studies, classical insight problems were

85 presented, and the performance scores were found to be correlated with polymorphisms of two

86 SNPs in DRD2 (rs 1800467 \& rs6278) (Zhang \& Zhang, 2016) and one SNP in COMT

87 (rs5993883) (Jiang, Shang \& Su, 2015). As insight problem solving is suggested to reflect a kind

88 of convergent thinking (Jiang, Shang \& Su, 2015), these results provide preliminary evidence for

89 the possible genetic involvement for convergent thinking.

90 Creativity can be defined in a broader sense in the cognitive domain beyond the divergent

91 and convergent thinking processes. A variety of basic cognitive functions and capabilities have

92 been reported to be correlated with creativity measures. To create something new, one should 
93 first be able to store and retrieve information so that one can easily make associations between

94 concepts or objects (Avitia \& Kaufman, 2014). Hereby, the creative process can benefit from

95 working memory by switching between response categories and breaking away from ineffective

96 approaches to a solution (Lee \& Therriault, 2013). Evidence showed that when increasing

97 working memory load, insight problem-solving performance was hindered whereas divergent

98 thinking performance was enhanced (Lin \& Lien, 2013). Personality traits can influence

99 creativity achievement as well. It has been shown that openness and extraversion contributed to

100 the quantity and diversity of creative products (Kandler et al., 2016). Creativity is also linked to

101 general intelligence. Investment theory argues that intelligence is a necessary but not sufficient

102 condition of creativity (Sternberg, 2012). Studies showed that intelligence contributed to both

103 divergent thinking and convergent thinking (Batey, Furnham \& Safiullina, 2010; Lee \&

104 Therriault, 2013).

105 Accordingly, studies are suggesting a possible genetic basis for these cognitive functions

106 and capabilities as well. For long-term memory, rs6265 in the BDNF gene has been found

107 associated significantly with performance on the auditory delayed element of the Wechsler

108 Memory Scale (WMS-III) (Yeh et al., 2012). The same SNP appeared to be related to visual and

109 spatial components of memory (Yogeetha et al., 2013). Also, another SNP, rs17070145, has an

110 association with memory functions (Witte et al., 2016). An SNP within COMT gene, rs4680,

111 plays an important role in working memory since there are findings on its association with

112 prefrontal activation during various working memory tasks (Meyer-Lindenberg et al., 2006; 
113 Papaleo et al., 2014). This SNP also has an impact on children's prefrontal cognitive functions

114 (Diamond et al., 2004). The genetic basis of personality has also been well documented.

115 Systematically investigations using genome-wide association (GWAS) and meta-analysis can be

116 found in literatures, with different results for different nationalities (Terracciano et al., 2010;

117 Kim et al., 2015; Moor et al., 2015). Notably, rs16921695 and rs912765 were found to be related

118 to openness and extraversion in Asian population (Kim et al., 2015). When it comes to

119 intelligence, there are several linkages between SNPs and intelligence supported. The gene

120 locations above, rs4680 and rs6265, are two examples (Harris et al., 2006; Barnett et al., 2007).

121 Besides, rs42352 has been found to be associated with hippocampal volume in Han Chinese

122 population and further moderate the association between hippocampal volume and Raven's

123 Progressive Matrices performance (Zhu et al., 2014).

124 To sum up, the state-of-the-art investigations on genetic influences of creativity has mainly

125 employed tests for divergent thinking and focused on genes within the dopamine system.

126 Considering the multifaceted definition of creativity, it is necessary to explore convergent

127 thinking capability as well as other related cognitive functions and capabilities.

128 In the present study, we explored possible genetic influences of both divergent and

129 convergent thinking capabilities within the same group of participants. In contrast to previous

130 studies that selected SNPs on the basis of hypothesized biological mechanisms, here we selected

131 the SNPs from a cognition-based criterion, taking into consideration the SNPs with a potential

132 contribution to creativity-related cognitive functions and capabilities. Our results are expected to 
133 provide complementary evidence toward a complete overview of the genetic influences on

134 creativity.

\section{Method}

136 Participants

137321 healthy Chinese undergraduates (160 females, mean age 20 years, ranging from 17 to

13824 years) recruited from two universities (161 from Tsinghua University and 160 from China

139 Agricultural University) in Beijing participated in the study. The participants were given either

140 course credits (for the participants from Tsinghua University) or cash (40 yuan, for the other

141 participants) for their participation. In addition, individualized gene reports were delivered to all

142 participants free of charge. All participants provided their written consent. The study was

143 conducted in accordance with the Declaration of Helsinki and approved by the local Ethics

144 Committee of Tsinghua University.

145 A total number of 35 participants were excluded from further analysis: 5 did not complete

146 the web-based scale; 27 participants failed to pass the attention check item in the web-based

147 scale; 3 failed to complete the paper-and-pencil task. Therefore, a final number of 286

148 participants (144 females, 144 from Tsinghua University and 142 from China Agricultural

149 University) was included in the current analysis. The demographic characteristics of the final

150 sample were summarized in Table 1.

151 Procedure 
152 To assess the participants' divergent and convergent thinking capability, they first completed a

153 paper-and-pencil measurement composed of the Guildford Unusual Using Test (UUT) (Guilford,

154 1967) and the Remote Associates Test (RAT) (Mednick, 1968; Chinese version from Xiao, Yao,

$155 \&$ Qiu, 2016). Here UUT is used to reflect divergent thinking capability whereas RAT is

156 employed to reflect convergent thinking capability. Both UUT and RAT have time limits: 5

157 minutes for each UUT task and 5 minutes for RAT task. UUT output three component scores

158 (fluency, flexibility, and originality) on the participants' divergent thinking capability and RAT

159 reported a single score on the participants' convergent thinking capability. The participants then

160 provided their buccal swabs for genotyping. They also took part in the Raven's Advanced

161 Progressive Matrices (RAPM) test for measuring intelligence. They were asked to fill out a web-

162 based scale later using their own computers for the necessary demographical information (age,

163 gender, student ID, etc.), as well as the Creative Achievement Questionnaire (CAQ). Detailed

164 explanations on these tests and their scoring methods are provided in the Appendix.

\section{Genotyping}

166 Based on previous studies as reviewed in Introduction, 18 single nucleotide polymorphisms

167 (SNPs) (rs10251794, rs1042778, rs1079597, rs12601685, rs16921695, rs17070145, rs1799913,

168 rs1800497, rs2576037, rs35855737, rs362584, rs42352, rs4680, rs5993883, rs6265, rs644148,

169 rs6832769, rs912765) as well as the DRD4 repeat-number polymorphism were chosen in the

170 HapMap database and NCBI SNP database. An overview of all the SNPs included in the present

171 study as well as our considerations are provided in Table 2. 
172 The buccal swab was obtained from each participant, and the DNA was extracted using

173 TIANamp Genomic DNA Kit (Tiangen, Beijing, China). Purified genomic DNA was eluted in

$17450 \mathrm{uL}$ elution buffer, and $50 \mathrm{ng}$ of DNA was used for PCR. And the Primer3 software program

175 was used to design primers. The SNP genotyping work was typed by SNaPshot Multiplex kit.

176 The current method for DRD4 repeat-number polymorphism is genotyping based on short

177 tandem repeat (STR)-PCR involving coamplification of a panel of STR loci by multiplex PCR

178 and downstream fragment length analysis (FLA), usually performed by capillary electrophoresis.

179 Data Analysis

180 We first tested whether the genotype distributions were in Hardy-Weinberg equilibrium and

181 calculated the linkage disequilibrium (LD) patterns of the SNPs with Shesis before further

182 analysis. The genotypes of SNPs were coded dichotomously through a dominant model, i.e.,

183 combining the homozygotes for less proportion with heterozygotes to balance the sample volume

184 between groups (Zhang, Zhang \& Zhang, 2014a; Jiang, Shang \& Su, 2015). The genetic

185 influence on divergent thinking was investigated using multivariate analysis of variance

186 (MANOVA), with the three component scores from UUT as dependent variables. Three post-hoc

187 analyses of variance (ANOVA) analyses were then performed to identify the influential gene loci

188 for each component. The corresponding analyses of covariance (ANCOVA) were conducted in

189 parallel with age, gender, university source (dichotomously coded for the two universities) and

190 RAPM score as covariates in order to control for intelligence and other confounding factors.

191 Prior to performing MANOVA, Box's M tests were conducted to examine the homogeneity of 
192 covariance matrices. Likewise, ANOVA and ANCOVA were performed for convergent thinking

193 with the RAT score as dependent variable. The participants' real-life creative achievements and

194 personality traits were not included as they provided information beyond the scope of the present

195 study. These data will be used elsewhere in future studies.

\section{Result}

197 The mean score of all 286 participants on RAT (reflecting convergent thinking) was 9.56 with a

198 standard deviation $(S D)$ of 2.57 . The mean scores of fluency, flexibility, and originality

199 components on UUT (reflecting divergent thinking) were standardized scores with zero mean

200 value. The fluency score ranged from -4.59 to $6.24(S D=1.85)$, the flexibility score ranged from

$201-4.83$ to $4.42(S D=1.65)$, and the originality score ranged from -3.30 to $6.83(S D=1.80)$. The

202 pairwise Pearson correlations between the RAT score and the three UUT component scores are

203 shown in Table 3. Significant correlations were observed within the three UUT component

204 scores, but all of them did not significantly correlate with the RAT score. The adjusted CAQ

205 score was significantly correlated with all the three UUT component scores but not the RAT

206 score. The correlation between the creativity measures, age and intelligence are also provided in

207 Table 3.

208 Table 4 summarizes the minor allele frequency (MAF) and other detailed information for the

20917 SNPs, except for rs35855737 and DRD4 due to their limited diversity in the current sample

210 (TT genotype and Non-7R for all participants at rs35855737 and DRD4, respectively). The

211 genotype distributions of 16 out of 17 SNPs were in Hardy-Weinberg equilibrium. The linkage 
212 disequilibrium (LD) patterns of the SNPs above were calculated with Shesis (Figure 1). Strong LD

213 was observed between rs1079597 and rs1800497 $\left(r^{2}=.89\right)$. Therefore, rs644148, rs35855737, and

214 DRD4 are excluded in the following analysis for either violation of Hardy-Weinberg equilibrium

215 or limited diversity.

216 Genetic influences on divergent thinking

217 A MANOVA analysis was conducted using fluency, flexibility, and originality component

218 scores from UUT as dependent variables to identify the genes correlated with divergent thinking

219 capability. Box's M tests reported that the data for the comparison groups were of homogeneous

220 covariance matrices for all measures $(p s>0.001)$. Among all SNPs, significant differences were

221 observed between rs2576037 groups $\left(F(3,277)=4.043, \mathrm{p}=0.008, \eta^{2}=0.041\right)$. One SNP

222 (rs6832769) approached statistical significance: $F(3,277)=2.492, p=0.06, \eta^{2}=0.026$. All p-

223 values were uncorrected.

224 For each individual component score, there are significant differences between rs2576037

225 groups on fluency $\left(F=9.731, p=0.002, \eta^{2}=0.033\right)$ and originality $\left(F=10.996, p=0.001, \eta^{2}=\right.$

226 0.037). The results remained after controlling for covariates. Post-hoc t-tests revealed that TT

227 carriers scored higher on both components $(p=0.006$ and $p=0.002$ for fluency and orignality

228 conponent scores, respectively). The ANOVA and ANCOVA results are listed in Table 5.

229 Genetic influences on convergent thinking

230 An ANOVA analysis was conducted using the RAT score as the dependent variable to

231 identify genes correlated with convergent thinking capability. ANOVA results showed allelic 
232 variations of two SNPs significantly associated with the RAT performance: $r$ 362584 $(F=7.643$,

$\left.233 p=0.006, \eta^{2}=0.026\right)$ and $\operatorname{rs} 5993883\left(F=6.652, p=0.01, \eta^{2}=0.023\right) . \quad$ Post-hoc t-tests

234 revealed that rs362584 GG homozygotes had lower RAT score $(p=0.031)$, so did rs5993883 TT

235 homozygotes $(p=0.024)$. These results remained after controlling for age and intelligence as

236 covariates, as shown in Table 6.

\section{Discussion}

238 The present study, for the first time, investigated the genetic basis for both the divergent and

239 the convergent thinking components of creativity. The SNPs of rs5993883 in COMT, rs362584

240 in SNAP25, rs2576037 in KATNAL2 were found to be associated with one of the creativity test

241 scores. As the selection of the SNPs was based on a broader scope considering the creativity-

242 related cognitive functions and capabilities, our results provide new information for the genetic

243 influences on creativity.

244 Previous studies on the genetic basis of creativity have mainly focused on the biological

245 mechanisms of divergent thinking, consequently limiting the exploration of possible candidate

246 genes. By broadening the scope to include cognition-related genes, our result revealed the

247 association between rs2576037 in KATNAL2 gene and the UUT performances on the fluency

248 and the originality components. According to the TiGRE database, the expression level of

249 KATNAL2 on the brain is relatively high (Liu et al., 2008). The production of this gene is a

250 protein similar to the sub-unit A of the p60 katanin protein, to which axonal growth is sensitive

251 (Karabay et al., 2004). Alternatively, rs2576037 might affect creativity through the medium 
252 effect of its relating conscientiousness personality (de Moor et al., 2012), as one recent study has

253 reported a connection between conscientiousness and everyday creativity in a cohort of Chinese

254 undergraduate students (Chen, 2016). However, none of the four SNPs reported in previous

255 studies (rs 1800497, rs1042778, rs5993883 and rs4680) showed significant influences on

256 divergent thinking scores. This discrepancy needs to be addressed in future studies, e.g. by

257 having a more complete recording of the demographic information of the participants for a more

258 detailed comparison between studies. Nevertheless, the present study provided evidences on

259 additional SNPs that contribute to divergent thinking.

260 Our exploration of convergent thinking capabilities revealed the contributions from two

261 SNPs, rs5993883 in COMT and rs362584 in SNAP25. While there were no previous genetic

262 studies directly investigating convergent thinking, the finding of rs5993883 in COMT is in

263 accordance with one previous study on insight problem solving (Jiang, Shang \& Su, 2015). In

264 contrast to the insight problem tasks, RAT was used in the present study, which is believed to be

265 a more direct measurement of convergent thinking. The rs362584 in SNAP25, however, has not

266 been reported in previous creativity-related studies. The product of SNAP25, a presynaptic

267 plasma membrane protein, is a key protein for the docking and fusion of synaptic and other

268 vesicles (Veit Michael, Söllner Thomas H. \& Rothman James E., 1996). It is suggested that high

269 levels of expression of this gene in specific areas of the adult brain are related to nerve terminal

270 plasticity (Oyler et al., 1989; Osen-Sand et al., 1993). Furthermore, the genetic variants in

271 SNAP25 have been found associated with cognitive ability (Gosso et al., 2006) and cognitive 
272 disorder (Liu et al., 2017). Since creativity is a complex cognitive process, these discoveries

273 provided hints for the relation between rs362584 and creativity. Moreover, rs362584 has been

274 reported to be related to neuroticism, which was proposed to be negatively related to creativity as

275 well (Furnham et al., 2009).

276 Most importantly, we found distinct SNPs for divergent and convergent thinking,

277 suggesting possible different genetic mechanisms behind the two processes. Such a finding is in

278 accordance with a variety of psychological and physiological studies. For instance, the different

279 influences of divergent and convergent thinking by working memory load argued for distinct

280 cognitive processes underlying these two creative thinking processes (Lin \& Lien, 2013; Lee \&

281 Therriault, 2013); the two creative thinking processes were associated with different personalities

282 as well, with openness and agreeableness for divergent thinking and agreeableness for

283 convergent thinking (Myszkowski et al., 2015); moreover, the influence of chronotype and its

284 interaction with asynchrony on convergent thinking but not divergent thinking performances,

285 suggests potential different physiological bases (Simor \& Polner, 2017). Therefore, our finding

286 could be viewed as complementary to previous studies, providing the first piece of evidence

287 toward distinct genetic mechanisms for the two creative thinking processes.

288 There are several limitations of the present study. First, the sample size is relatively small.

289 The limited sample size have restricted the number of variables to be simultaneously explored,

290 e.g. the interaction between different genes, the influence of personality on genes, etc. Second,

291 all participants were Chinese students, therefore the findings need to be interpreted with 
292 cautious, especially when considering people of different races. Third, the 19 SNPs were selected

293 considering their potential contribution to creativity-related cognitive functions and capabilities.

294 A more comprehensive understanding of the genetic basis of creativity, would require genome-

295 wide association studies (GWAS) with possibly a much larger population.

\section{Conclusions}

297 Taking a cognition-based perspective, the present study investigated the genetic basis for both

298 the divergent and the convergent thinking components of creativity. Three SNPs (rs5993883,

299 rs362584, and rs2576037) out of the selected 19 SNPs were found to be associated with

300 creativity. Divergent and convergent thinking capabilities were related to distinct contributing

301 SNPs. Our results provide new evidence for the genetic basis of creativity and reveal the

302 important role of gene polymorphisms in divergent and convergent thinking.

303

304 Acknowledgment

305 The authors would like to thank Dr. Jing Qian from Tsinghua University, Dr. Xiang Li, Mr.

306 Jin Wu from China Agricultural University for recruiting the participants, Ms. Ning Wu, Ms.

307 Yujin Wang from Repconex Co, for their technical support during data collection and

308 preprocessing. 


\section{APPENDIX}

\section{Unusual Using Test}

311 The UUT was developed by Guilford to access examinees' divergent thinking capability

312 (Guilford, 1967). Examinees were asked to list as many possible uses for common prompts as

313 they can. In the present study, 'newspaper' and 'plastic bottle' were used as prompts and

314 participants were given 5 minutes for each prompt.

315 Four independent coders (two for each prompt) blind to the identity of participants were

316 invited to code the answers together, with discrepancies resolved by consensus. For each prompt,

317 two coders simplified the answers by cutting unnecessary particles. For example, "be used to

318 swat flies" and "we use newspapers to swat flies" are both coded as "swatting flies". Impossible

319 uses and incomprehensible expressions were excluded while performing the coding. Another two

320 coders (one for each prompt) were then invited to categorize the coded answers according to a

321 predetermined catalog (Qun, 2015). Following Dippo's scoring procedure (Dippo \& Kudrowitz,

322 2013): Originality score was defined as the number of uses that occur in less than $10 \%$ of all the

323 answers; Fluency score was calculated as the total number of uses in one participant's answer;

324 Flexibility was calculated as the total number of categories. The final score is obtained by

325 calculating the sum of the $\mathrm{z}$-score of the two prompts, which composes three components:

326 fluency, flexibility, and originality.

327 Remote Associates Test 
328 RAT is a well-established convergent thinking test where participants are required to find the

329 only solution for the association among three presented cue words (Lee \& Therriault, 2013).

330 Here we used the Chinese version of the Remote Associates Test, developed by Beijing Key

331 Laboratory of Behavior and Mental Health (Xiao, Yao \& Qiu, 2016). Participants were required

332 to come up with the word associated with three presented words that appeared to be semantically

333 unrelated. The Chinese version of RAT provided standard answers for reference. The score of

334 RAT was defined as the number of items where a participant reached the single, correct answer.

335 In the present study, a time limit of 5 minutes was given to all participants for 15 items.

336 Raven's Advanced Progressive Matrices

337 The APM (Raven, C Raven \& H Court, 1998) is a standardized test that can be conducted either

338 individually or in groups. It is composed of a series of matrices with the lower right corner

339 missing. Participants are required to choose the correct answer from 8 alternatives provided

340 below to fill the matric. The complete APM includes two sets. The difficulty of 12 problems

341 constituting Set I is equivalent to problems in the Standard Progressive Matrices, whereas the

342 difficulty of 36 problems in Set $\mathbb{I}$ is greater. All problems are arranged such that the difficulty

343 increases progressively. In this study, two problems from Set I were used as a practice, and

344 participants answered all 36 problems from Set II in 40 minutes to assess intellectual efficiency.

345 Real-Life Creative Achievement

346 Participants' real-life creative achievement was accessed through an adjusted version of Creative

347 Achievement Questionnaire (CAQ) (Carson, Peterson \& Higgins, 2005). CAQ is a self-report 
348 checklist of creativity in 10 different domains. In this study, we adjusted the questionnaire by

349 choosing nine domains and changing the description of specific achievements to fit with Chinese

350 college students' life. The adjusted CAQ used in the current study had good reliability

351 (Cronbach's $\alpha=0.719$ ). For criterion-related validity, the CAQ score and UUT performance have

352 a significant positive correlation (Pearson $r=0.216, p<0.01$ ), however, the correlation between

353 CAQ and RAT score is not significant (Pearson $r=-0.005, p=0.932$ ). This part of data was not

354 used in the present study and will be used elsewhere.

355 Attention Check Item

356 One additional question was embedded in the web-based scale (for demographic information and

357 CAQ) to check the validity of the participants' answer. In this item, we explicitly asked the

358 participants to choose "strongly disagree" on a five-point Likert Scale from 0 (strongly disagree)

359 to 4 (strongly agree). The participants that failed in this item were excluded from data analysis. 
361

362

363

364

365

366

367

368

369

370

371

372

373

374

375

376

377

378

379

380

381

382

383

384

385

386

387

388

389

390

391

392

393

394

395

396

397

398

\section{Reference}

Avitia MJ., Kaufman JC. 2014. Beyond g and c: The relationship of rated creativity to long-term storage and retrieval (Glr). Psychology of Aesthetics, Creativity, and the Arts 8:293-302. DOI: $10.1037 / \mathrm{a} 0036772$.

Barnett JH., Heron J., Ring SM., Golding J., Goldman D., Xu K., Jones PB. 2007. GenderSpecific Effects of the Catechol- O -Methyltransferase Val 108/158 Met Polymorphism on Cognitive Function in Children. American Journal of Psychiatry 164:142-149. DOI: 10.1176/ajp.2007.164.1.142.

Batey M., Furnham A., Safiullina X. 2010. Intelligence, general knowledge and personality as predictors of creativity. Learning and Individual Differences 20:532-535. DOI: 10.1016/j.lindif.2010.04.008.

Brophy DR. 2001. Comparing the Attributes, Activities, and Performance of Divergent, Convergent, and Combination Thinkers. Creativity Research Journal 13:439-455. DOI: 10.1207/S15326934CRJ1334_20.

Carson SH., Peterson JB., Higgins DM. 2005. Reliability, Validity, and Factor Structure of the Creative Achievement Questionnaire. Creativity Research Journal 17:37-50. DOI: 10.1207/s15326934crj1701_4.

Chen B-B. 2016. Conscientiousness and everyday creativity among Chinese undergraduate students. Personality and Individual Differences 102:56-59. DOI: 10.1016/j.paid.2016.06.061. De Dreu CKW., Baas M., Roskes M., Sligte DJ., Ebstein RP., Chew SH., Tong T., Jiang Y., Mayseless N., Shamay-Tsoory SG. 2014. Oxytonergic circuitry sustains and enables creative cognition in humans. Social Cognitive and Affective Neuroscience 9:1159-1165. DOI:

\subsection{3/scan/nst094.}

Diamond A., Briand L., Fossella J., Gehlbach L. 2004. Genetic and Neurochemical Modulation of Prefrontal Cognitive Functions in Children. American Journal of Psychiatry 161:125-132. DOI: 10.1176/appi.ajp.161.1.125.

Diedrich J., Benedek M., Jauk E., Neubauer AC. 2015. Are creative ideas novel and useful? Psychology of Aesthetics, Creativity, and the Arts 9:35-40. DOI: 10.1037/a0038688.

Dippo C., Kudrowitz B. 2013. Evaluating The Alternative Uses Test of Creativity. In: 2013 NCUR.

Furnham A., Crump J., Batey M., Chamorro-Premuzic T. 2009. Personality and ability predictors of the "Consequences" Test of divergent thinking in a large non-student sample. Personality and Individual Differences 46:536-540. DOI: 10.1016/j.paid.2008.12.007.

Gosso MF., de Geus EJC., van Belzen MJ., Polderman TJC., Heutink P., Boomsma DI., Posthuma D. 2006. The SNAP-25 gene is associated with cognitive ability: evidence from a family-based study in two independent Dutch cohorts. Molecular Psychiatry 11:878-886. DOI: 10.1038/sj.mp.4001868.

Guilford JP. 1967. The nature of human intelligence. 
399 Harris SE., Fox H., Wright AF., Hayward C., Starr JM., Whalley LJ., Deary IJ. 2006. The brain400 derived neurotrophic factor Val66Met polymorphism is associated with age-related change in 401 reasoning skills. Molecular Psychiatry 11:505-513. DOI: 10.1038/sj.mp.4001799.

402 Jiang W., Shang S., Su Y. 2015. Genetic influences on insight problem solving: the role of 403 catechol-O-methyltransferase (COMT) gene polymorphisms. Frontiers in Psychology 6. DOI: 404 10.3389/fpsyg.2015.01569.

405 Kandler C., Riemann R., Angleitner A., Spinath FM., Borkenau P., Penke L. 2016. The nature of 406 creativity: The roles of genetic factors, personality traits, cognitive abilities, and environmental 407 sources. Journal of Personality and Social Psychology 111:230-249. DOI:

$40810.1037 / \mathrm{pspp} 0000087$.

409 Karabay A., Yu W., Solowska JM., Baird DH., Baas PW. 2004. Axonal Growth Is Sensitive to 410 the Levels of Katanin, a Protein That Severs Microtubules. Journal of Neuroscience 24:5778411 5788. DOI: 10.1523/JNEUROSCI.1382-04.2004.

412 Kim B-H., Kim H-N., Roh S-J., Lee MK., Yang S., Lee S., Sung Y-A., Chung H., H Cho N., 413 Shin C., Sung J., Kim H-L. 2015. GWA meta-analysis of personality in Korean cohorts. Journal 414 of human genetics 60. DOI: 10.1038/jhg.2015.52.

415 Lee CS., Therriault DJ. 2013. The cognitive underpinnings of creative thought: A latent variable 416 analysis exploring the roles of intelligence and working memory in three creative thinking 417 processes. Intelligence 41:306-320. DOI: 10.1016/j.intell.2013.04.008.

418 Lin W-L., Lien Y-W. 2013. The Different Role of Working Memory in Open-Ended Versus 419 Closed-Ended Creative Problem Solving: A Dual-Process Theory Account. Creativity Research 420 Journal 25:85-96. DOI: 10.1080/10400419.2013.752249.

421 Liu Y-S., Dai X., Wu W., Yuan F-F., Gu X., Chen J-G., Zhu L-Q., Wu J. 2017. The Association 422 of SNAP25 Gene Polymorphisms in Attention Deficit/Hyperactivity Disorder: a Systematic 423 Review and Meta-Analysis. Molecular Neurobiology 54:2189-2200. DOI: 10.1007/s12035-016424 9810-9.

425 Liu X., Yu X., Zack DJ., Zhu H., Qian J. 2008. TiGER: A database for tissue-specific gene 426 expression and regulation. BMC Bioinformatics 9:271. DOI: 10.1186/1471-2105-9-271.

427 Mayseless N., Uzefovsky F., Shalev I., Ebstein RP., Shamay-Tsoory SG. 2013. The association 428 between creativity and 7R polymorphism in the dopamine receptor D4 gene (DRD4). Frontiers 429 in Human Neuroscience 7. DOI: 10.3389/fnhum.2013.00502.

430 Mednick S. 1962. The associative basis of the creative process. Psychological Review 69:220431 232. DOI: $10.1037 / \mathrm{h} 0048850$.

432 Mednick SA. 1968. The Remote Associates Test*. The Journal of Creative Behavior 2:213-214. 433 DOI: 10.1002/j.2162-6057.1968.tb00104.x.

434 Meyer-Lindenberg A., Nichols T., Callicott JH., Ding J., Kolachana B., Buckholtz J., Mattay 435 VS., Egan M., Weinberger DR. 2006. Impact of complex genetic variation in COMT on human 436 brain function. Molecular psychiatry 11:867. 
437 Moor MHM de., Berg SM van den., Verweij KJH., Krueger RF., Luciano M., Vasquez AA., 438 Matteson LK., Derringer J., Esko T., Amin N., Gordon SD., Hansell NK., Hart AB., Seppälä I., 439 Huffman JE., Konte B., Lahti J., Lee M., Miller M., Nutile T., Tanaka T., Teumer A., Viktorin 440 A., Wedenoja J., Abecasis GR., Adkins DE., Agrawal A., Allik J., Appel K., Bigdeli TB., 441 Busonero F., Campbell H., Costa PT., Smith GD., Davies G., Wit H de., Ding J., Engelhardt BE., 442 Eriksson JG., Fedko IO., Ferrucci L., Franke B., Giegling I., Grucza R., Hartmann AM., Heath 443 AC., Heinonen K., Henders AK., Homuth G., Hottenga J-J., Iacono WG., Janzing J., Jokela M., 444 Karlsson R., Kemp JP., Kirkpatrick MG., Latvala A., Lehtimäki T., Liewald DC., Madden PAF., 445 Magri C., Magnusson PKE., Marten J., Maschio A., Medland SE., Mihailov E., Milaneschi Y., 446 Montgomery GW., Nauck M., Ouwens KG., Palotie A., Pettersson E., Polasek O., Qian Y., 447 Pulkki-Råback L., Raitakari OT., Realo A., Rose RJ., Ruggiero D., Schmidt CO., Slutske WS., 448 Sorice R., Starr JM., Pourcain BS., Sutin AR., Timpson NJ., Trochet H., Vermeulen S., 449 Vuoksimaa E., Widen E., Wouda J., Wright MJ., Zgaga L., Porteous D., Minelli A., Palmer AA., 450 Rujescu D., Ciullo M., Hayward C., Rudan I., Metspalu A., Kaprio J., Deary IJ., Räikkönen K., 451 Wilson JF., Keltikangas-Järvinen L., Bierut LJ., Hettema JM., Grabe HJ., Duijn CM van., Evans 452 DM., Schlessinger D., Pedersen NL., Terracciano A., McGue M., Penninx BWJH., Martin NG., 453 Boomsma DI. 2015. Meta-analysis of Genome-wide Association Studies for Neuroticism, and 454 the Polygenic Association With Major Depressive Disorder. JAMA Psychiatry 72:642-650. DOI: 455 10.1001/jamapsychiatry.2015.0554.

456 de Moor MHM., Costa PT., Terracciano A., Krueger RF., de Geus EJC., Toshiko T., Penninx 457 BWJH., Esko T., Madden P a. F., Derringer J., Amin N., Willemsen G., Hottenga J-J., Distel 458 MA., Uda M., Sanna S., Spinhoven P., Hartman CA., Sullivan P., Realo A., Allik J., Heath AC., 459 Pergadia ML., Agrawal A., Lin P., Grucza R., Nutile T., Ciullo M., Rujescu D., Giegling I., 460 Konte B., Widen E., Cousminer DL., Eriksson JG., Palotie A., Peltonen L., Luciano M., Tenesa 461 A., Davies G., Lopez LM., Hansell NK., Medland SE., Ferrucci L., Schlessinger D., 462 Montgomery GW., Wright MJ., Aulchenko YS., Janssens ACJW., Oostra BA., Metspalu A., Abecasis GR., Deary IJ., Räikkönen K., Bierut LJ., Martin NG., van Duijn CM., Boomsma DI.

464 465

466

467

468

469

470

471

472

473

474
2012. Meta-analysis of genome-wide association studies for personality. Molecular Psychiatry 17:337-349. DOI: 10.1038/mp.2010.128.

Myszkowski N., Storme M., Davila A., Lubart T. 2015. Managerial creative problem solving and the Big Five personality traits: Distinguishing divergent and convergent abilities. The Journal of Management Development; Bradford 34:674-684.

Osen-Sand A., Catsicas M., Staple JK., Jones KA., Ayala G., Knowles J., Grenningloh G., Catsicas S. 1993. Inhibition of axonal growth by SNAP-25 antisense oligonucleotides in vitro and in vivo. Nature 364:445. DOI: 10.1038/364445a0.

Oyler GA., Higgins GA., Hart RA., Battenberg E., Billingsley M., Bloom FE., Wilson MC. 1989. The identification of a novel synaptosomal-associated protein, SNAP-25, differentially expressed by neuronal subpopulations. The Journal of Cell Biology 109:3039-3052. 
475 Papaleo F., Burdick MC., Callicott JH., Weinberger DR. 2014. Epistatic interaction between

476 COMT and DTNBP1 modulates prefrontal function in mice and in humans. Molecular

477 Psychiatry 19:311-316. DOI: 10.1038/mp.2013.133.

478 Qun Y. 2015. The Relationship between Mind Wandering and Creative Problem Solving.

479 Master's thesis Thesis. College of Teacher Education of Zhejiang Normal University.

480 Raven J., C Raven J., H Court J. 1998. Manual for Raven's Progressive Matrices and Vocabulary

481 Scales

482 Reuter M., Roth S., Holve K., Hennig J. 2006. Identification of first candidate genes for

483 creativity: A pilot study. Brain Research 1069:190-197. DOI: 10.1016/j.brainres.2005.11.046.

484 Runco MA., Noble EP., Reiter-Palmon R., Acar S., Ritchie T., Yurkovich JM. 2011. The

485 Genetic Basis of Creativity and Ideational Fluency. Creativity Research Journal 23:376-380.

486 DOI: $10.1080 / 10400419.2011 .621859$.

487 Simor P., Polner B. 2017. Differential influence of asynchrony in early and late chronotypes on

488 convergent thinking. Chronobiology International 34:118-128. DOI:

$48910.1080 / 07420528.2016 .1246454$.

490 Sternberg RJ. 2012. The Assessment of Creativity: An Investment-Based Approach. Creativity

491 Research Journal 24:3-12. DOI: 10.1080/10400419.2012.652925.

492 Sternberg RJ., Lubart TI. 1999. The concept of creativity: Prospects and paradigms. In:

493 Sternberg RJ [Ed ed. Handbook of creativity. Cambridge University Press (New York, NY, US),

494 3-15, Chapter ix, 490 Pages.

495 Takeuchi H., Tomita H., Taki Y., Kikuchi Y., Ono C., Yu Z., Sekiguchi A., Nouchi R., Kotozaki

496 Y., Nakagawa S., Miyauchi CM., Iizuka K., Yokoyama R., Shinada T., Yamamoto Y., Hanawa

497 S., Araki T., Hashizume H., Kunitoki K., Sassa Y., Kawashima R. 2015. The associations among

498 the dopamine D2 receptor Taq1, emotional intelligence, creative potential measured by divergent

499 thinking, and motivational state and these associations' sex differences. Frontiers in Psychology

500 6. DOI: 10.3389/fpsyg.2015.00912.

501 Terracciano A., Sanna S., Uda M., Deiana B., Usala G., Busonero F., Maschio A., Scally M.,

502 Patriciu N., Chen W-M., Distel MA., Slagboom EP., Boomsma DI., Villafuerte S., Śliwerska E.,

503 Burmeister M., Amin N., Janssens ACJW., van Duijn CM., Schlessinger D., Abecasis GR.,

504 Costa Jr PT. 2010. Genome-wide association scan for five major dimensions of personality.

505 Molecular Psychiatry 15:647-656. DOI: 10.1038/mp.2008.113.

506 Veit Michael, Söllner Thomas H., Rothman James E. 1996. Multiple palmitoylation of

507 synaptotagmin and the t-SNARE SNAP-25. FEBS Letters 385:119-123. DOI: 10.1016/0014-

508 5793(96)00362-6.

509 Witte AV., Köbe T., Kerti L., Rujescu D., Flöel A. 2016. Impact of KIBRA Polymorphism on

510 Memory Function and the Hippocampus in Older Adults. Neuropsychopharmacology 41:781-

511 790. DOI: 10.1038/npp.2015.203. 
512 Xiao W., Yao X., Qiu Y. 2016. Constructing Chinese Remote Associates Test (RAT) with

513 Application of Item Response Theory. Acta Scientiarum Naturalium Universitatis Pekinensis

514 52:354-362.

515 Yeh T-K., Hu C-Y., Yeh T-C., Lin P-J., Wu C-H., Lee P-L., Chang C-Y. 2012. Association of

516 polymorphisms in BDNF, MTHFR, and genes involved in the dopaminergic pathway with

517 memory in a healthy Chinese population. Brain and Cognition 80:282-289. DOI:

518 10.1016/j.bandc.2012.06.005.

519 Yogeetha BS., Haupt LM., McKenzie K., Sutherland HG., Okolicsyani RK., Lea RA., Maher

520 BH., Chan RCK., Shum DHK., Griffiths LR. 2013. BDNF and TNF- $\alpha$ polymorphisms in

521 memory. Molecular Biology Reports 40:5483-5490. DOI: 10.1007/s11033-013-2648-6.

522 Yu Q., Zhang S., Zhang JH. 2017. Association of Dopamine D2 Receptor Gene with Creative

523 Ideation. Creativity Research Journal 29:108-113. DOI: 10.1080/10400419.2017.1302758.

524 Zabelina DL., Colzato L., Beeman M., Hommel B. 2016. Dopamine and the Creative Mind:

525 Individual Differences in Creativity Are Predicted by Interactions between Dopamine Genes

526 DAT and COMT. PLOS ONE 11:e0146768. DOI: 10.1371/journal.pone.0146768.

527 Zhang S., Zhang J. 2016. The Association of DRD2 with Insight Problem Solving. Frontiers in

528 Psychology 7. DOI: 10.3389/fpsyg.2016.01865.

529 Zhang S., Zhang J. 2017. The association of TPH genes with creative potential. Psychology of

530 Aesthetics, Creativity, and the Arts 11:2-9. DOI: 10.1037/aca0000073.

531 Zhang S., Zhang M., Zhang J. 2014a. An Exploratory Study on DRD2 and Creative Potential.

532 Creativity Research Journal 26:115-123. DOI: 10.1080/10400419.2014.874267.

533 Zhang S., Zhang M., Zhang J. 2014b. Association of COMT and COMT-DRD2 interaction with

534 creative potential. Frontiers in Human Neuroscience 8. DOI: 10.3389/fnhum.2014.00216.

535 Zhu B., Chen C., Xue G., Moyzis RK., Dong Q., Chen C., Li J., He Q., Lei X., Wang Y., Lin C.

536 2014. The SEMA5A gene is associated with hippocampal volume, and their interaction is

537 associated with performance on Raven's Progressive Matrices. NeuroImage 88:181-187. DOI:

538 10.1016/j.neuroimage.2013.11.035.

539 


\section{Table $\mathbf{1}$ (on next page)}

Descriptive statistics of demographic characteristics

Note: $\mathrm{N}$ refers to the number of participants. THU is the abbreviation of Tsinghua University. CAU is the abbreviation of China Agricultural University. 
Table 1 Descriptive Statistics of Demographic Characteristics

\begin{tabular}{lccccc}
\hline \hline & N(female)/N(total) & Mean age & SD(age) & Min(age) & Max(age) \\
\hline THU & $55 / 144$ & 19.75 & 1.213 & 18 & 23 \\
CAU & $89 / 142$ & 20.35 & 1.284 & 17 & 24 \\
All & $144 / 286$ & 20.05 & 1.283 & 17 & 24 \\
\hline
\end{tabular}

2 Note: $\mathrm{N}$ refers to the number of participants. THU is the abbreviation of Tsinghua University.

3 CAU is the abbreviation of China Agricultural University.

4 
Table 2 (on next page)

Related cognitive functions or capabilities of selected SNPS 
Table 2. Related cognitive functions or capabilities of selected SNPs

\begin{tabular}{|c|c|c|c|}
\hline SNP & Gene & Reference & $\begin{array}{c}\text { Related cognitive functions } \\
\text { or capabilities }\end{array}$ \\
\hline rs 1042778 & OXTR (oxytocin receptor) & $\begin{array}{l}\text { (De Dreu et al., } \\
\text { 2014) }\end{array}$ & creative ideation in UUT \\
\hline rs1799913 & $\begin{array}{l}\text { TPH1 (tryptophan } \\
\text { hydroxylase 1) }\end{array}$ & (Reuter et al., & figural and numeric creativity \\
\hline rs 1800497 & $\begin{array}{l}\text { DRD2 (dopamine receptor } \\
\text { D2) }\end{array}$ & 2006) & verbal creativity \\
\hline rs5993883 & $\begin{array}{l}\text { COMT (catechol-O- } \\
\text { methyltransferase) }\end{array}$ & $\begin{array}{c}\text { (Jiang, Shang \& } \\
\text { Su, 2015) }\end{array}$ & insight task performance \\
\hline rs42352 & SEMA5A (semaphorin 5A) & $\begin{array}{l}\text { (Zhu et al., } \\
\text { 2014) }\end{array}$ & $\begin{array}{c}\text { moderation between } \\
\text { hippocampal volume and } \\
\text { Raven's Progressive Matrices } \\
\text { performance }\end{array}$ \\
\hline rs17070145 & $\begin{array}{c}\text { WWC1 }(\text { WW and C2 domain } \\
\text { containing } 1 \text { ) }\end{array}$ & $\begin{array}{l}\text { (Witte et al., } \\
\text { 2016) }\end{array}$ & $\begin{array}{c}\text { memory performance by the } \\
\text { Rey Auditory Verbal } \\
\text { Learning Test (AVLT) }\end{array}$ \\
\hline rs4680 & COMT & $\begin{array}{l}\text { (Meyer- } \\
\text { Lindenberg et } \\
\text { al., 2006) }\end{array}$ & working memory \\
\hline rs6265 & $\begin{array}{l}\text { BDNF (brain-derived } \\
\text { neurotrophic factor) }\end{array}$ & $\begin{array}{l}\text { (Yeh et al., } \\
\text { 2012) }\end{array}$ & $\begin{array}{l}\text { intelligence by the Wechsler } \\
\text { Memory Scale (WMS-III) }\end{array}$ \\
\hline rs1079597 & DRD2 & $\begin{array}{l}\text { (Fischer, Lee \& } \\
\text { Verzijden, } \\
\text { 2018) }\end{array}$ & extraversion and neuroticism \\
\hline rs6832769 & $\begin{array}{c}\text { CLOCK (clock circadian } \\
\text { regulator) }\end{array}$ & & agreeableness \\
\hline rs644148 & $\begin{array}{c}\text { ZNF180 (zinc finger protein } \\
180)\end{array}$ & $\begin{array}{l}\text { (Terracciano et } \\
\text { al., 2010) }\end{array}$ & openness \\
\hline rs10251794 & $\begin{array}{c}\text { CNTNAP2 (contactin } \\
\text { associated protein-like 2) }\end{array}$ & & openness \\
\hline
\end{tabular}




\begin{tabular}{|c|c|c|c|}
\hline rs362584 & $\begin{array}{l}\text { SNAP25 (synaptosome- } \\
\text { associated protein } 25 \text { ) }\end{array}$ & & neuroticism \\
\hline rs 12601685 & $\begin{array}{c}\text { OR1A2 (olfactory receptor } \\
\text { family } 1 \text { subfamily A } \\
\text { member } 2 \text { ) }\end{array}$ & $\begin{array}{l}\text { (Kim et al., } \\
\text { 2013) }\end{array}$ & neuroticism \\
\hline rs35855737 & $\begin{array}{c}\text { MAGI1 (membrane } \\
\text { associated guanylate kinase, } \\
\text { WW and PDZ domain } \\
\text { containing 1) }\end{array}$ & $\begin{array}{l}\text { (Moor et al., } \\
2015 \text { ) }\end{array}$ & neuroticism \\
\hline rs 16921695 & $\begin{array}{c}\text { IMPAD1 (inositol } \\
\text { monophosphatase domain } \\
\text { containing 1) }\end{array}$ & $\begin{array}{l}\text { (Kim et al., } \\
2015)\end{array}$ & openness \\
\hline rs912765 & LMO4 (LIM domain only 4) & & conscientiousness \\
\hline rs 2576037 & $\begin{array}{c}\text { KATNAL2 (katanin catalytic } \\
\text { subunit A1 like } 2 \text { ) }\end{array}$ & $\begin{array}{l}\text { (de Moor et al., } \\
\text { 2012) }\end{array}$ & conscientiousness \\
\hline
\end{tabular}




\section{Table 3 (on next page)}

Pearson correlations of the creativity tasks, age, and intelligence

${ }^{*} p<.05 .{ }^{* *} p<.01$. 
Table 3. Pearson correlations of the creativity tasks, age, and intelligence

\begin{tabular}{|c|c|c|c|c|c|c|}
\hline$p$-value & Flexibility & Originality & RAT & CAQ & Age & Intelligence \\
\hline Fluency & $0.63 * *$ & $0.90 * *$ & 0.02 & $0.23 * *$ & $-0.14^{*}$ & $0.18 * *$ \\
\hline Flexibility & & $0.47 * *$ & 0.02 & $0.14^{*}$ & $-0.16 * *$ & 0.11 \\
\hline Originality & & & -0.01 & $0.20 * *$ & $-0.15^{*}$ & $0.18 * *$ \\
\hline RAT & & & & -0.01 & $-0.19^{*}$ & $0.19 * *$ \\
\hline CAQ & & & & & -0.11 & -0.01 \\
\hline Age & & & & & & -0.07 \\
\hline
\end{tabular}




\section{Table 4(on next page)}

SNPs genotype frequence

Note. $\mathrm{MAF}=$ minor allele frequency; $\mathrm{HWE}=$ Hardy-Weinberg equilibrium 
Table 4. SNPs genotype frequencies

\begin{tabular}{|c|c|c|c|c|}
\hline SNP & MAF & Genotype & Frequency & HWE $p$ \\
\hline rs10251794 & 0.24 & TT/TA/AA & $0.62 / 0.34 / 0.04$ & 0.99 \\
\hline rs1042778 & 0.41 & GG/TG/TT & $0.85 / 0.15 / 0.01$ & 0.88 \\
\hline rs1079597 & 0.25 & $\mathrm{CC} / \mathrm{CT} / \mathrm{TT}$ & $0.34 / 0.49 / 0.17$ & 0.97 \\
\hline rs12601685 & 0.13 & $\mathrm{CC} / \mathrm{CG} / \mathrm{GG}$ & $0.83 / 0.17 / 0.01$ & 0.97 \\
\hline rs16921695 & 0.32 & GG/GT/TT & $0.02 / 0.29 / 0.68$ & 0.84 \\
\hline rs17070145 & 0.48 & $\mathrm{CC} / \mathrm{CT} / \mathrm{TT}$ & $0.06 / 0.33 / 0.61$ & 0.77 \\
\hline rs1799913 & 0.32 & GG/GT/TT & $0.32 / 0.45 / 0.24$ & 0.20 \\
\hline rs1800497 & 0.33 & GG/GA/AA & $0.36 / 0.49 / 0.14$ & 0.78 \\
\hline rs 2576037 & 0.44 & $\mathrm{CC} / \mathrm{CT} / \mathrm{TT}$ & $0.21 / 0.51 / 0.28$ & 0.98 \\
\hline rs362584 & 0.2 & GG/GA/AA & $0.57 / 0.39 / 0.04$ & 0.34 \\
\hline rs42352 & 0.47 & $\mathrm{TT} / \mathrm{TA} / \mathrm{AA}$ & $0.24 / 0.46 / 0.3$ & 0.46 \\
\hline rs4680 & 0.37 & GG/GA/AA & $0.59 / 0.36 / 0.06$ & 0.99 \\
\hline rs5993883 & 0.48 & GG/GT/TG/TT & $0.19 / 0.43 / 0.07 / 0.31$ & 0.94 \\
\hline rs6265 & 0.2 & $\mathrm{CC} / \mathrm{CT} / \mathrm{TT}$ & $0.24 / 0.51 / 0.24$ & 0.89 \\
\hline rs644148 & 0.26 & $\mathrm{GG} / \mathrm{GT}$ & $0.73 / 0.26$ & 0.03 \\
\hline rs6832769 & 0.28 & GG/GA/AA & $0.08 / 0.42 / 0.49$ & 0.96 \\
\hline rs912765 & 0.4 & $\mathrm{CC} / \mathrm{CT} / \mathrm{TT}$ & $0.44 / 0.43 / 0.13$ & 0.67 \\
\hline
\end{tabular}

2 Note. $\mathrm{MAF}=$ minor allele frequency; $\mathrm{HWE}=$ Hardy-Weinberg equilibrium 


\section{Table 5(on next page)}

\section{ANOVA and ANCOVA results on UUT component scores}

Note: Three component scores of UUT were analyzed by ANOVA and ANCOVA. Intelligence, age, gender and university source were used as covariables in ANCOVA.

Bolded values indicate significant effect. 


\begin{tabular}{|c|c|c|c|c|c|c|c|}
\hline \multirow[b]{2}{*}{ Variable } & \multirow[b]{2}{*}{ Gene } & \multicolumn{3}{|c|}{ ANOVA } & \multicolumn{3}{|c|}{ ANCOVA } \\
\hline & & $F$ & $p$ & $\eta^{2}$ & $F$ & $p$ & $\eta^{2}$ \\
\hline \multirow[t]{15}{*}{ Flexibility } & rs 10251794 & 1.373 & 0.242 & 0.005 & 0.806 & 0.37 & 0.003 \\
\hline & rs 1042778 & 3.917 & 0.049 & 0.014 & 2.674 & 0.103 & 0.009 \\
\hline & rs1079597 & 0.003 & 0.955 & 0 & 0.038 & 0.846 & 0 \\
\hline & rs 12601685 & 0.002 & 0.966 & 0 & 0.089 & 0.765 & 0 \\
\hline & rs 16921695 & 0.358 & 0.55 & 0.001 & 0.665 & 0.416 & 0.002 \\
\hline & rs 17070145 & 0.023 & 0.879 & 0 & 0.007 & 0.935 & 0 \\
\hline & rs1799913 & 0.152 & 0.697 & 0.001 & 0.002 & 0.963 & 0 \\
\hline & rs1800497 & 0.219 & 0.64 & 0.001 & 0.456 & 0.5 & 0.002 \\
\hline & rs 2576037 & 0.865 & 0.353 & 0.003 & 0.531 & 0.467 & 0.002 \\
\hline & rs362584 & 0.001 & 0.973 & 0 & 0.164 & 0.686 & 0.001 \\
\hline & rs42352 & 0.017 & 0.896 & 0 & 0.108 & 0.743 & 0 \\
\hline & rs 4680 & 0.045 & 0.832 & 0 & 0.019 & 0.891 & 0 \\
\hline & rs5993883 & 0.185 & 0.667 & 0.001 & 0.328 & 0.567 & 0.001 \\
\hline & rs6265 & 0.155 & 0.694 & 0.001 & 0.431 & 0.512 & 0.002 \\
\hline & rs6832769 & 0.002 & 0.968 & 0 & 0.017 & 0.897 & 0 \\
\hline & rs912765 & 0.016 & 0.898 & 0 & 0.072 & 0.789 & 0 \\
\hline
\end{tabular}




\begin{tabular}{|c|c|c|c|c|c|c|c|}
\hline \multirow[t]{16}{*}{ Fluency } & rs 10251794 & 0.327 & 0.568 & 0.001 & 0.075 & 0.784 & 0 \\
\hline & rs1042778 & 0.104 & 0.747 & 0 & 0.174 & 0.676 & 0.001 \\
\hline & rs1079597 & 0.208 & 0.649 & 0.001 & 0.227 & 0.634 & 0.001 \\
\hline & rs 12601685 & 0.001 & 0.976 & 0 & 0.066 & 0.798 & 0 \\
\hline & rs 16921695 & 0.001 & 0.976 & 0 & 0.277 & 0.599 & 0.001 \\
\hline & rs 17070145 & 1.166 & 0.281 & 0.004 & 0.953 & 0.33 & 0.003 \\
\hline & rs1799913 & 1.002 & 0.318 & 0.004 & 0.424 & 0.516 & 0.002 \\
\hline & rs1800497 & 0.26 & 0.611 & 0.001 & 0.292 & 0.589 & 0.001 \\
\hline & rs 2576037 & 9.731 & 0.002 & 0.033 & 8.475 & 0.004 & 0.029 \\
\hline & rs362584 & 0.035 & 0.851 & 0 & 0.15 & 0.699 & 0.001 \\
\hline & rs 42352 & 1.416 & 0.235 & 0.005 & 2.674 & 0.103 & 0.009 \\
\hline & rs 4680 & 0.068 & 0.795 & 0 & 0.029 & 0.866 & 0 \\
\hline & rs5993883 & 0.384 & 0.536 & 0.001 & 0.438 & 0.509 & 0.002 \\
\hline & rs6265 & 1.786 & 0.182 & 0.006 & 2.518 & 0.114 & 0.009 \\
\hline & rs6832769 & 4.605 & 0.033 & 0.016 & 3.928 & 0.048 & 0.014 \\
\hline & rs912765 & 0.004 & 0.95 & 0 & 0.119 & 0.73 & 0 \\
\hline \multirow[t]{3}{*}{ Originality } & rs10251794 & 0.164 & 0.686 & 0.001 & 0.005 & 0.945 & 0 \\
\hline & rs 1042778 & 0.214 & 0.644 & 0.001 & 0.174 & 0.677 & 0.001 \\
\hline & rs1079597 & 0.221 & 0.639 & 0.001 & 0.31 & 0.578 & 0.001 \\
\hline
\end{tabular}




\begin{tabular}{|c|c|c|c|c|c|c|}
\hline rs 12601685 & 0.387 & 0.534 & 0.001 & 0.105 & 0.746 & 0 \\
\hline rs16921695 & 0.248 & 0.619 & 0.001 & 0.008 & 0.93 & 0 \\
\hline rs17070145 & 0.439 & 0.508 & 0.002 & 0.257 & 0.613 & 0.001 \\
\hline rs1799913 & 1.836 & 0.176 & 0.006 & 1.04 & 0.309 & 0.004 \\
\hline rs1800497 & 0.543 & 0.462 & 0.002 & 0.754 & 0.386 & 0.003 \\
\hline rs 2576037 & 10.996 & 0.001 & 0.037 & 10.056 & 0.002 & 0.035 \\
\hline rs362584 & 0.113 & 0.737 & 0 & 0.036 & 0.85 & 0 \\
\hline rs42352 & 0.967 & 0.326 & 0.003 & 2.773 & 0.097 & 0.01 \\
\hline rs4680 & 0.428 & 0.513 & 0.002 & 0.466 & 0.496 & 0.002 \\
\hline rs5993883 & 0.013 & 0.909 & 0 & 0.013 & 0.909 & 0 \\
\hline rs 6265 & 0.516 & 0.473 & 0.002 & 0.82 & 0.366 & 0.003 \\
\hline rs6832769 & 4.529 & 0.034 & 0.016 & 4.496 & 0.035 & 0.016 \\
\hline rs912765 & 0.432 & 0.511 & 0.002 & 0.287 & 0.593 & 0.001 \\
\hline
\end{tabular}

2 Note: Three component scores of UUT were analyzed by ANOVA and ANCOVA. Intelligence, 3 age, gender and university source were used as covariables in ANCOVA.

4 Bolded values indicate significant effect.

5

6 


\section{Table 6(on next page)}

\section{ANOVA and ANCOVA results on RAT scores}

Note: RAT scores were analyzed by ANOVA and ANCOVA. Age, intelligence, gender and university source were used as covariables in ANCOVA.

Bolded values indicate significant effect. 
Table 6. ANOVA and ANCOVA results on RAT scores

\begin{tabular}{|c|c|c|c|c|c|c|}
\hline \multirow[b]{2}{*}{ gene } & \multicolumn{3}{|c|}{ ANOVA } & \multicolumn{3}{|c|}{ ANCOVA } \\
\hline & $F$ & $p$ & $\eta^{2}$ & $F$ & $p$ & $\eta^{2}$ \\
\hline rs10251794 & 2.256 & 0.134 & 0.008 & 0.918 & 0.339 & 0.003 \\
\hline rs1042778 & 0.028 & 0.868 & 0 & $0.103^{b}$ & 0.749 & 0 \\
\hline rs1079597 & 0.585 & 0.445 & 0.002 & 0.463 & 0.497 & 0.002 \\
\hline rs12601685 & 0.822 & 0.365 & 0.003 & 1.826 & 0.178 & 0.007 \\
\hline rs16921695 & 0 & 0.996 & 0 & 0.558 & 0.456 & 0.002 \\
\hline rs 17070145 & 1.827 & 0.178 & 0.006 & 1.39 & 0.239 & 0.005 \\
\hline rs1799913 & 1.772 & 0.184 & 0.006 & 3.773 & 0.053 & 0.013 \\
\hline rs1800497 & 0.884 & 0.348 & 0.003 & 0.673 & 0.413 & 0.002 \\
\hline rs 2576037 & 0.084 & 0.772 & 0 & 0.001 & 0.978 & 0 \\
\hline rs362584 & 7.643 & 0.006 & 0.026 & 5.619 & 0.018 & 0.02 \\
\hline rs42352 & 3.395 & 0.066 & 0.012 & 1.435 & 0.232 & 0.005 \\
\hline rs4680 & 0.369 & 0.544 & 0.001 & 0.392 & 0.532 & 0.001 \\
\hline rs5993883 & 6.652 & 0.01 & 0.023 & 7.517 & 0.007 & 0.026 \\
\hline rs6265 & 0.266 & 0.606 & 0.001 & 0.545 & 0.461 & 0.002 \\
\hline rs6832769 & 0.079 & 0.779 & 0 & 0.051 & 0.821 & 0 \\
\hline rs912765 & 0.106 & 0.745 & 0 & 0.04 & 0.841 & 0 \\
\hline
\end{tabular}


2 Note: RAT scores were analyzed by ANOVA and ANCOVA. Age, intelligence, gender and 3 university source were used as covariables in ANCOVA.

4 Bolded values indicate significant effect. 
Figure 1

Linkage disequilibrium map.

Numbers in squares indicate the degree of LD $\left(r^{2}\right.$ value*100) between any two SNPs

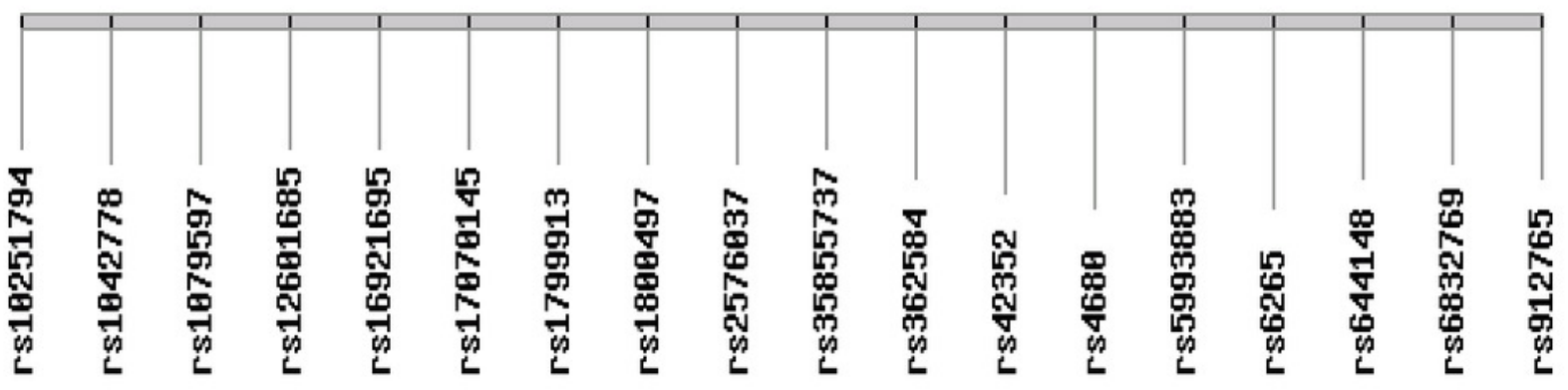

$\begin{array}{llllllllllllllllll}1 & 2 & 3 & 4 & 5 & 6 & 7 & 8 & 9 & 10 & 11 & 12 & 13 & 14 & 15 & 16 & 17 & 18\end{array}$ $\begin{array}{lllllllllllllllll}0 & 0 & 0 & 0 & 0 & 0 & 0 & 0 & 0 & 0 & 0 & 0 & 9 & 1 & 0 & 0 & 0\end{array}$

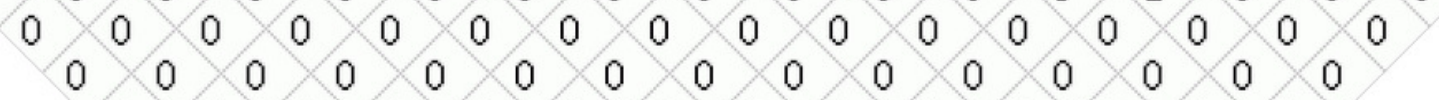
$\begin{array}{llllllllllllllllllll}1 & 0 & 0 & 0 & 0 & 0 & 0 & 0 & 0 & 0 & 0 & 0 & 0 & 0\end{array}$ $\begin{array}{lllllllllllllllll}0 & 0 & 89 & 0 & 0 & 0 & 0 & 0 & 0 & 0 & 3 & 0 & 1\end{array}$ $\begin{array}{lllllllllllllll}0 & 0 & 0 & 0 & 0 & 0 & 0 & 1 & 0 & 0 & 0\end{array}$

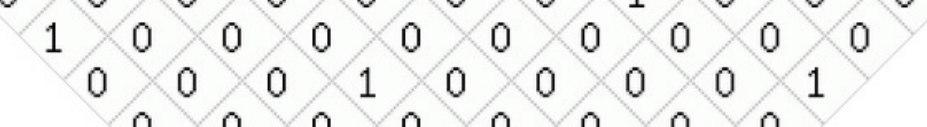

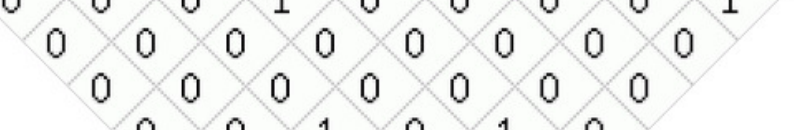

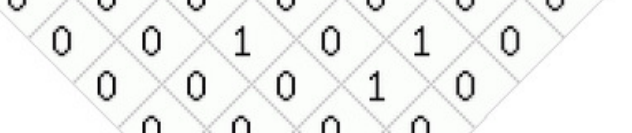
$0 / 1 / 0 \% 0$ 0,0 